\title{
The Future of Japanese Economy*
}

\section{By Yoshihiro INAYAMA**}

Thank you very much Mr. Chairman for your kind introduction. It was indeed flattering.

Now, ladies and gentlemen, I consider it an honour and pleasure to have been given the chance to speak to you on the occasion of the 100th Grand Meeting of the Iron and Steel Institute of Japan. Today, I would like to speak on several subjects that I have been thinking about lately.

\section{On Japanese Economy and World Economy}

Many people are now saying that the Japanese economy, and even the economy of the entire world, is facing extraordinary difficulties. But, it seems to me there is no really extraordinary difficulty in a man's life except when he is about to die. Even if we are doomed, there is no escape for us; we are all of us bound to this country or to this planet. Yet, I maintain that there is nothing to be frightened about if a person recognizes that there exists a great current in life, and that it is utterly unnecessary for us to try to fight against it. I believe that for any person who is resolved to adapt himself to that current, that flow of events, there is nothing to be afraid of.

Now, what then is extraordinary? To me, many extraordinary things have occurred in Japan precisely because Japan was able to develop itself economically to its present state so quickly. There would have been nothing extraordinary today at all, if that age of material scarcity, the age in which people of my generation were brought up and trained, had continued. But now, people shout out the word " extraordinary" whenever the rate of inflation rises to two digits from a one digit figure. To me, this isn't worth the use of the word "extraordinary" at all. To me, it is extraordinary not to be thinking about ways to prevent prices from rising by two digit rates.

Then, what should we do to keep consumer prices from rising? There are theories maintaining that it is enough to suppress prices that should otherwise be rising. By this, they mean public utilities charges. But, whenever anything that is bound to rise in the natural course of events is forcibly held back, strains inevitably appear somewhere. When these strains accumulate, yet larger strains will appear. It is because the great flow of natural order is resisted.

\section{On Price and Cost}

Then, what is the flow of natural order? And how does it apply to the lowering of prices? It is simply this: In order to lower the price, the cost of production must be reduced. Take the example of coffee. People complain that at about 300 yen per cup, coffee prices are too high. Yet, I have never heard of a coffee shop owner making a lot of money. This is because he has to pay a great deal for the shop and for the help. I was told that the price of land in Japan is some 24 times what it is in America and perhaps more. The poor coffee shop owner has to maintain his shop on that expensive land, paying quite a lot for his land, for his shop, and for the labour of employees. If you want a cheap cup of coffee, therefore, all you have to do is lower the price of land and labour, that is to say, the costs. Easy, isn't it?

People call the suppressing of the rise in prices, price policy. I say it isn't a policy at all. To me, price policy is something that induces lower costs. In Great Britain, for example,-long ago, when the Heavy and Chemical Industries boom was about to begin,- the responsible people in government recognized that the most important thing they could do was keep the price of steel low. They analysed the situation carefully and concluded that their purpose could best be served by a low price of coal. What they did was to supply the iron and steel industry with cheap coal on a preferential basis. I think this is an example of true price policy. To suppress the price of steel by force is not worthy of the name "policy." The advanced nations are all aware of this, whereas to our government, the suppression of price increases is price policy. I believe suppression can never be the basis for a sound policy for anything.

\section{On the Japanese Steel Industry and the American Stand}

Now let me return to the issue of Japan facing a very severe economic situation. I submit that in order to understand the present situation fully, we need to study why Japan, a country which no one before the war could ever imagine as acquiring its present strength, has come to flourish and reconstruct itself from total defeat. It seems to me, that behind this development was the insight held by some Americans of the role they wanted Japan to play in their global endeavour of abolishing war and maintaining peace. To do that, America felt it was essential to help out the Japanese economy. That is to say, I think for Americans the Second World War was the war to end all wars. In spite of this, they failed to

\footnotetext{
Special Anniversary Lecture of the 100th ISIJ Meeting held at Kyushu University, Higashi-ku, Fukuoka 812, on October 19, 1980, and published in Tetsu-to-Hagané, 67 (1981), 225, in Japanese. English version received February 4, 1981.

** Honorary Membership of ISIJ; Chairman of Keizai Dantai Rengokai (The Federation of Economic Organizations); Board Chairman of Nippon Steel Corporation.
} 
establish world peace immediately following the termination of the last war because of the drawing of the Iron Gurtain, the Berlin Crisis and other such incidents. The Americans had to start the peace process all over again. To keep peace, the economic as well as military power of free nations had to be maintained to balance those of socialist or communist countries.

This, I think, was the basic policy of the US. That is, it felt that unless the free countries grew stronger economically, they would be defeated by socialist or communist countries. Japan, too, they saw, should grow economically in order to complement the solidarity of free nations.

It was about that time that I read an article by Mr. Strachey in Nippon Keizai Shimbun. He is a former-Marxist turned British Labour parliamentarian. In that article, he called for a yearly average economic growth of $5 \%$ in the free nations of the world in order to compete with communist countries. What struck me in that article besides his theory was the fact that though he made particular mention of the US, Great Britain, Germany, and Japan, he did not mention France. I remember wondering why. Anyway, this is why the US actively helped Japan to recover, expecting her to achieve an economic growth of over $5 \%$, thus contributing to the strength of the free world.

And it was because of this policy that the reconstruction and rationalization of our iron and steel industry succeeded. When we approached the US for financial aid, Mr. Sherman Adams, then a Special Presidential Counsellor, said to us: So, you have no blast furnaces to make iron with, OK, we'll lend you our blast furnace technologies; so, you have no money, OK, we'll loan you money; so, you have no raw materials, OK, we'll help you get them; come to me for help, and I will help you in any way I can, for Japan must grow along free economy principles. And he opened the way for us to draw a loan from the World Bank. The amount may have been tiny by today's standards, but it was the precious first spark that enabled us to obtain larger loans from Japanese banks. With those funds, we were able to buy the most modern equipment from abroad to build an iron and steel industry and thus the foundation for our entire economy that we have today. We owe very much to the US.

\section{On the Power Margin of the Japanese Steel In- dustry}

Today the Japanese steel industry is in possession of equipment capable of a yearly output of over 140 million tons. Besides that, almost all our equipment is not yet ten years old. We are producing now about 110 million tons a year with those modern machines and facilities. That means we have some 30 million tons of extra, idle capacity. I predict that the time will come when this margin will prove its true worth.

They are idle now, to be sure. But let us not forget that they were had very inexpensively. If you want to build comparable capacity now, you will have to pay very, very dearly indeed. In the US, estimates are being made for renovation investment. The figures cited are 900 to 1200 dollars per ton of steel produced. It will soon be the same here, too. I am sure we will soon come to appreciate the value of our surplus capacity. I say this because I am firmly convinced that as long as the population keeps growing, the demand for steel is sure to increase, even though the rate of increase itself may become smaller. It is then that the real power of Japan's steel industry will manifest itself thanks to this extra margin of production capacity.

I will have to warn you, though, that that time may not come as early as you or the government would hope. This means that we will have to maintain our marginal equipment for some time to come. It won't be easy; it will be a great burden for us. But after that, I believe today's annoyance will become tomorrow's treasure. Therefore, I believe we have plenty of reserve power to overcome the oil price rise. This is how I see the situation.

\section{On Structural Change of Industry}

There are people who are advocating the total renovation of the industrial structure of Japan. I don't like that idea at all. The world is right in the midst of the Heavy Industry and Chemical Industry Age, and I firmly believe this will not change for a very, very long time to come, well beyond the life time of us here today. My reasons are simple: People will keep multiplying, and so will their desires; to satisfy these desires, we have no other option than utilizing mechanical power. No matter how hard a man may try, making things better and making more of them, over a certain level, is beyond human ability.

For example, there are one billion Chinese. Overwhelmed by their sheer number and afraid of their potential, many influential men used to clamour for the early establishment of friendly relations. I did not agree. That is rather, I agreed with the idea of establishing friendly relations but not for reasons of fear. There is no reason to be afraid of any people who lack sophisticated machines, no matter how many of them there are. For, without mechanization, a people's productive power can never be raised by much, nor can the state make its people happy. Look at China today. They have finally recognized this after many years. That is why now we can and will help them help themselves. And, it is on that basis that we will build a true friendship.

All that means is this: Machines are made of iron; and iron means mechanization, and mechanization yields a rise in living standards and civilization. This is all another definition of the Age of Heavy and Chemical Industries. This means further that when the time comes that all machines can be fashioned out of non-iron materials, vinyl, for example, I will be the first to advocate throwing away iron altogether and trusting vinyl to do the job. We make iron because iron is needed; we do not have to bother with iron, if and when iron becomes unnecessary. But can 
you imagine that ever happening?

Yet there are so-called Conversionists who want us to scrap our surplus equipment simply because it has no immediate use, and who want to see Japan undergo a sort of metamorphosis into some other type of industrial society. Their mistake lies in placing our basic industries and their materials on a par with the industries that work those materials. Their theories are all founded on a mixing-up of those three things, discussing them all on the same plane. It's just not good thinking.

Another thing. Under the free enterprise system, any commodity for which there is no demand automatically becomes unsalable, and the prevailing conditions, also, automatically change. Those bright Conversionist boys ignore this and try to change the industrial structure according to what they dreamed up on a piece of paper. What they advocate amounts to this: Manufacture unsalable things, then the price will come down; good for the people and for those who planned it. If this kind of theory is allowed to dominate the economy, I declare to you that such an economy is just no good for promoting the happiness of the people. It takes wisdom to alter anything; the industrial structure is no exception. I do not think the Conversionists are as wise as they think they are, nor can I believe we are blessed with so many wisemen today.

\section{On Free Economy}

Animals are incapable of making things. That is why they must compete with each other for food, or fight each other to the death in order that one may survive. To me, this is what lies behind the law of natural selection in the animal kingdom.

But human beings are different. They are animals with the ability to manufacture things. To maintain their lives, first they produce things, then they use them. This is the basis of economy. Is it any wonder that the animal kingdom does not have this word, economy?

Whenever I emphasize production, however, people accuse me of "manufacturer's haughtiness". I don't mean that at all. What I mean is that to produce and to connect that to consumption is the economy. This means further that the existence of needed things and unneeded things is only a temporary condition in this world. Unneeded things will disappear in the natural course of events: Without any aid from artificial manipulation, things will arrange themselves into proper order under the free enterprise system. The free nations all have adopted the free enterprise principle because they know this is the best working economy.

Understanding this, we can appreciate how successful American notions have been. Right after the war, we were told that free enterprise economies were doomed to collapse soon. According to that theory, free enterprise economies were destined to destroy themselves by recurring cycles of brisk business and bad business, by panics, and by internal competition. The American notions were very much to the con- trary. They felt that free enterprise economies were destined to develop and become better. And they rallied their friends around the banner of free economy. The results are as you can see today: The free enterprise economies have prospered, while the socialist or communist countries are hard pressed to satisfy their peoples' material demands.

\section{On Competition, Contest, and Rivalry}

Whether this prosperity is good for people or not is an entirely different proposition. Whatever that answer may be, it will still remain that we have achieved prosperity. The reason for this success is simple: The free economy eschews monopoly. There are any number of enterprising companies in a given category of business. They compete with each other for their own betterment. It has been this competitive spirit that gave birth to the driving power for free economies to develop themselves.

It seems to me, though, nowadays people are misconstruing this spirit. The point here is the usage of the word vitality. They say that the vitality in the free enterprise economy is the will to compete, and they take this to mean to fight and quarrel with each other. I say they are totally wrong. Men beating each other and hurting each other like wild beasts, I don't think that kind of competition should be called vitality.

Then what is the true vitality of the free enterprise system? I believe it is a virtue to be patient, to endure, to bear up, and to make the best of the situation. It is only through those endeavours that science can progress day by day. Your own research and quest, be it at your workshop or at your laboratory, for making better products, improving product yield and quality - that kind of research and quest is not a contest. It never has been. Trying to knock out rivals through price wars, and everyone getting knocked out in the end, can never lead to human happiness. This is a kind of contest that should rightfully be called excessive competition, which is a form of free enterprise in its worst possible interpretation. It may be a way for jungle beasts, but most decidedly not for homo sapiens. What we should be engaged in is humane competition. A friend of mine once wrote me a letter, in which he said that it is a competition-mindedness, rather than competition that supplies the vitality needed for the progress of mankind. His words have since become my own watch words.

Yes, what is called for is for us to study really hard and to compete with our skills. Not the dog-eat-dog contests like price wars, but rather the healthy rivalry of coming up with ways to cut your own costs. I submit that it is only this kind of competition that can supply the free economies of the world with the vitality they need for their own sound evolution.

\section{On Cooperation}

We live by forming a society; that means we cooperate with each other in addition to competing with each other. The same thing is true with a cor- 
poration, where we gather together, cooperate with each other, work hard with an animalistic motivation we call competition, all to reduce cost. Therefore, one-half of our activities are cooperative, while the other half are competitive. As I see it, this is how we help our society evolve.

But, there are people who try to pull your leg by alleging that no competition is possible where cooperation is at work. They say cooperation necessarily negates competition. I don't agree. What I say is: It is not competition or cooperation, but competition and cooperation. Some time ago,-it was soon before his demise-we had Professor Ichiro Nakayama* talk to us at one of the Nikkeiren** General Meetings. In his speech, one I shall never forget, he said that competition and cooperation are two sides of the same coin; one cannot exist without the other; we need both, and we need them in order to develop our society. He said further that contrary to popular belief, competition does not by itself lead to progress. Rickshas*** have evolved into automobiles. But it was not the result of rickshas competing with each other; it was due to technological innovation. That was what he told us, and his words struck an inner chord of mine, so beautifully, I almost cried.

\section{On Problems of Inflation and Energy}

Yet, it is true that at present world economies, be they free enterprise or centrally planned ones, have come to a sort of deadlock, and Japan's economy is no exception. To pursue human happiness by overcoming this difficulty, I am afraid that the free economies, as we used to know them, are inadequate. They need some changes because the environment in which they exist has undergone a certain change. What is it exactly that has changed, then?

In order to find an answer to this question, let us look back on history. We Japanese have made impressive progress during the time of peace we have had in recent years. And this prosperity of ours also coincided with the worldwide development and spreading of Chemical and Heavy Industries. We have built our prosperity primarily by developing our machinery industries. Our land is so small. The arable portion comprises only a small fraction of the overall land area, so obviously we cannot live on agriculture alone. Besides, we are not blessed with natural raw material resources. Yet we have succeeded in giving practically everyone in this country an affluent life by means of mass production with our machinery and all other industries. In short, we were ready for, and capable of accepting, the full impact of the Age of Chemical and Heavy Industries when it arrived.

Since 1970, however, a dark cloud has begun to appear on the horizon. What was this cloud? It was inflation. It has grown steadily ever since, until now unless we overcome inflation, we cannot expect our free economy to develop any further. This is our Number One problem.

In addition to this, we were hit by what is known as Oil Shocks. Since oil is a fundamental raw material for Chemical and Heavy Industries, any threat to oil is a direct threat to the industries themselves. As Japan must rely upon her Chemical and Heavy Industries for her existence, Japan will continue to be tossed about to and from by others unless she solve this problem of oil. This clearly means that we cannot continue our old course as it was laid down years ago. This is problem Number Two. That is, how to solve the dual problems of Inflation and Energy is the most crucial problem we face today.

Inflation: This is a problem no government or any certain individuals can solve single-handedly. When Mr. Gerald Ford made his first Presidential appearance on TV, he told Americans, in effect, "What do you think this red badge on my lapel is? This is the symbol of inflation, of a kind that we never experienced before. We must unite and make a concerted effort to lick this enemy of the people, just as we were united after the Japanese attack on Pearl Harbour."

He could not have been more correct. Yes, today's inflation is not the easy kind that government was able to handle all alone in the past. It is a new kind that nobody, neither Americans nor any other nation in the world, has ever experienced before. That is why Mr. Ford specifically called for his nation's solidarity.

The reason is that this inflation is rooted in labour costs. If you raise wages, and do not get a corresponding increase in production, the price of your product must rise. That is a part of the free enterprise system. This shows you how closely related labour costs and commodity prices are. If you don't want prices to go up and if you want to suppress inflation, it stands to reason that you must hold down wage raises. Raise wages, and prevent inflation and suppress prices; it just can't be done.

The trouble is this reasoning is hard for ordinary people to understand and accept. And our politicians must seek their votes. To get elected, politicians have to cater to ordinary people. That is why in Japan or America, or anywhere else in the democratic world, it is so hard to control inflation. Former U.S. President Richard Nixon once said in his Presidential Message to Congress that the particular inflation that they were facing was a kind entirely different from what they had had in the past. It was not the kind that might be solved by classic Keynesian manipulation of national finance or public expenditure, and that there was no way to solve it except by calling for good sense both on the part of management and on the part of labour in the productive industries.

\footnotetext{
* Dr. Econ., Professor, then Emeritus Professor of Hitotsubashi University, Tokyo. A theoretical economist, Prof. Nakayama was a leader of post-war Japanese economist.

** Nihon Keieisha Dantai Renmei (Japan Federation of Employers Association).

*** Jin-Riki-Sha, a man-drawn, single-seat, two-wheeled vehicle; used to be popular and common over 50 years ago.
} 
Let me add one more example. Professor Arnold Toynbee once remarked that the decline of Great Britain was attributable to the presence of two governments: One is the Government itself, and the second is the labour union. What he meant is the historical fact that around 1970, when full employment was reached, the power of labour unions became so great that wage hikes were demanded and obtained without an accompanying increase in production. This is how the present inflation started.

In reflection of this, Americans are now advocating the linking of wages to productivity. In the US, however, agreements have already been established between labour and management in many industries, including the steel and automotive industries, that stipulate that wages are to escalate in accordance with inflation. This certainly is no way to stop inflation. Opinions differ between the administration, the common man, enterprises, and labour on how to solve this dilemma. This, I think, is the picture in today's America as well as in today's Japan. To guarantee our people the benefit of a truly stable economy, we will have to modify the old ways in which the free economy system had been run.

Regarding the other problem of energy, the current theories all blame the finiteness of resources for today's difficulties. It may be true that oil is finite, but that does not mean that we have to give up, because we have wisdom, the wisdom with which we can develop alternative fuels. There are people who call for securing a stable supply of oil. But, when oil is bound to disappear eventually, I wonder how on earth can we can secure oil supplies. Besides, to secure something that is in somebody else's land and not our own is, to me, sheer impertinence and all wrong. No wonder they have gone completely astray.

What I believe is finite is not the resources but human desire. We hear that human desires are limitless, but our materialistic desires are as the good Lord made for every day dispensation. Of the 24 hours in a day, we spend 8 hours sleeping; how much can you consume within the remaining 16 hours, I dare ask. If I were to cut open your stomachs, I'm sure I'd find them pretty much filled. It seems to me that in reality we have an excess of things. If so, any talk of a rate of increase in food supply is nonsense. It is unnecessary. It is unnecessary for us to make things that are unnecessary. Making people make unnecessary things and making that an incentive to bring prices down-I don't think this kind of economy, if economy it really is, can stand at all.

Besides, we have to consider the fact that from now on the number of people over 65 years of an age will increase more and more. If you call them old people, one out of every three Japanese will soon be an old person. This will impose a tremendous burden on our economy. But, physiologically old people eat only a little, so that national food demand should become less. As for clothes, we all have plenty already. You've got only one body; I dare say, how can you wear two suits at a same time? I wonder how much more do we really need.

We all work for our living, that is to say, for clothes, food, and shelter. According to Maslow, among human desires, that for food is the strongest. When it is $60 \%$ satisfied, however, our next desire presents itself, and so on, and so forth; and after all those sundry desires are satisfied, the desire for honour comes up, which is last. But the desire for honour costs no money nor does it need materials. This means that, since the final desire of man is honour, human desire is finite materialistically.

\section{Conclusions}

It seems to me that now is the time for all of us to contemplate deeply about how to make Japan a comfortable and stable place to live even under a low growth economy, which is inevitable. Why, then, do we still keep paying so much attention to the rate of GNP increase? We don't have to pursue GNP any longer. We don't have to make it grow any more. Rather, we must plan ahead now about how to make enterprising companies stable. With our enterprises maintained at stable levels, the lives of our people working there will also be stable. Then, this will spread all over this land to make Japan and the Japanese stable. Therefore, we should no longer wish for growth; we should now wish for stabilization. This is my basic stand, and my final conclusion.

I thank you all for your attention. 